\title{
THE ROLE OF TECHNOLOGY PARKS IN THE ENTREPRENEURIAL PROCESS: THE CASE OF TECHNOLOGY PARK VARAŽDIN
}

\author{
Anica Hunjet, Emilija Ivetić, Goran Kozina \\ (1) University North, Varaždin, Croatia \\ (2) University North, Varaždin, Croatia \\ (3) University North, Varaždin, Croatia
}

\author{
Anica Hunjet \\ University North, Varaždin, Croatia \\ anica.hunjet@unin.hr \\ Article info \\ Paper category: Original scientific paper \\ Received: 29.6.2017. \\ Accepted: 30.3 .2018 \\ JEL classification: $\mathrm{M}_{21}, \mathrm{O}_{2}$
}

Keywords Entrepreneurship; Entrepreneurial venture; Technology park; Innovation 


\begin{abstract}
Purpose. The entrepreneurial process is a complicated structure defined by interaction of many factors. When analyzing entrepreneurship in the context of modern - day development of new technologies, technology parks are also being introduced in this process. Technology parks are specific forms which started their growth in the middle of twentieth century. They are viewed as places where technology, entrepreneurship, knowledge, innovation and creativity are being combined together in order to nurture the process of creating visions, ideas and new values. Technology parks are the nexus between academic community and ventures. The aim of this paper was to present the interaction between entrepreneurship and technology parks, and to identify the role of technology parks in today's entrepreneurial venture.

Design. Over time industrial economy has developed into information economy, which also has many forms. That lead to acknowledgement of the strength of connection between industry and know - how. Therefore this paper foremost defines the concepts of entrepreneurship and technology parks through their historic evolution and modalities of their interaction, that being the base for a case study. A case study was conducted in Technology park Varaždin in the period from March †th to March 13th 2016, using following methods. Firstly secondary data analysis was conducted (data acquired from available literature and business reports) which gave basis for a decision regarding primary data collecting and hypotheses proposal. Afterwards primary data analysis was conducted (data acquired using online survey method). Survey was conducted on population consisting of entrepreneurs whose companies are tenants of Technology park Varaždin. The mentioned research survey consisted of twenty questions divided into four sections.
\end{abstract}

Findings. Total of three hypotheses were proposed and tested in order to make tenants profiles and analysis of their habitat in Technology park Varaždin, and finally in order to identify the role of Technology park Varaždin in their entrepreneurial process. 


\section{INTRODUCTION}

Entrepreneurship is a concept developed at the same time as the concept of creating a new value, and it is being redefined all over again along with the emerging of new knowledge, studies, theories and political systems (Bobera, Hunjet, Kozina, $2015,15)$. Therefore, among many definitions of the term entrepreneurship, the one given by Jeffry A. Timmons sums up the essence of that process: the ability to create and build something from practically nothing (Hunjet, Kozina, 2014, 5).

The very person who engages into such entrepreneurial venture is the entrepreneur himself: it is a person who takes initiative, risk and seizes the opportunity that has presented itself. Entrepreneurial venture is a process consisting of four phases (Hisrich, Peters, Shepherd, 2011, 9): identification and opportunity assessment, business plan development, determining the resources needed and finally company management. That being said, it is obviously shown that special connection between entrepreneurship, creativity and innovation.

\section{HISTORICAL BACKGROUND AND EVOLUTION OF ENTREPRENEURSHIP AND TECHNOLOGY PARKS}

Historically, first entrepreneurial ventures are connected to the work of Marco Polo (13th and 14th century). The Middle Ages defines an entrepreneur as a person who performs the work and manages large projects, but does not take any risk. In the 17 th century entrepreneurship is connected to the risk taking. In the 18th century, as a consequence of industrialization, the difference between the entrepreneur and the person funding the entrepreneurial venture is becoming increasingly obvious.

In the end of the1gth century and in the beginning of the 2oth century there is no difference between the terms "entrepreneur" and "manager", while in the middle of the 2oth century entrepreneur is defined as an innovator as well.

In the 2oth century, according to (Brusić, Cvitanović, Gregov, Kutnjak, Tomić, Žanić, 2009, 16-17) we can identify five different phases:

- 1950s to 1960s: domination of large companies, mass production and consumption, the role of the private entrepreneurship is insignificant

- 1960s to the middle of 1970s: in Japan and Taiwan increased role of the workforce in SMEs, which is not the case in highly developed European countries; the oil crisis and the consequent social situation affects the development of active employment and self-employment

- second half of the 1970s to 1990s: intensive development of the computer industry, the mass media, franchising and musical - entertainment industry in USA

- the period of 1990s: the so-called years of entrepreneurship; development of the entrepreneurship around the world 
- the beginning of the 21st century: the flow of information through the Internet opened the possibility of globalization of small businesses and innovation became the main initiator.

The development of entrepreneurship in the Republic of Croatia was greatly influenced by the time spent in the political arrangements that did not know the concept of private ownership and entrepreneurial initiatives. Unfortunately, the consequences are still visible, especially as expressed in the lack of support of the administrative system, the education system and the perception of society in general. However, Croatia has a great tradition of artisan fraternities, guilds, unions and chambers (Hunjet, Kozina, Milkovć, 2012, 103-115).

Today, the Croatian entrepreneurship is increasingly relevant, and that is one of the consequences of joining the EU and opportunities for access to their acquired knowledge, experience and certainly financial assistance (Hunjet, Kozina, Kurečić, 2015, 620-629). The entrepreneurial process is carried out through several forms of legal persons, which is under the provisions of the Companies Act.

Looking at the evolution of the concept and content of entrepreneurship is obvious that global connectivity and availability of information, contacts and opportunities influenced the modern concept of entrepreneurship. It is particularly visible enormous expansion in the field of technological entrepreneurship, which is quite logical consequence of the ubiquity and availability of technology.

In this sense, it is extremely important notion of startup entrepreneurship. The term startup entrepreneurship appeared some ten years ago, and is primarily associated with technological entrepreneurship and dot - com bubble era. The emergence of the term is associated with the area of the United States, but the exact definition does not exist. U. S. Small Business Administration defines a startup as a business that is typically technologically oriented and has great growth potential (https://www. sba.gov/content/startups-high-growth-businesses). According to Steve Blank, startup is defined as a temporary organization which aims to create a model that can be repeated and have a tendency to increase (http://steveblank.com/2010/o1/25/ whats-a-startup-first-principles). Blank further argues that the startup entrepreneur begins his enterprise with a certain vision and a series of hypotheses about the product, customer, price, distribution channel - and must as soon as possible check the viability of his imaginary model.

Eric Ries defines a startup as an institution that was founded to create a new product or service in conditions of great uncertainty (Ries, 2013, 25). The key is that the product or service offered by startup is something innovative, that is new and associated with progress in every aspect. Ries further stresses that the startup venture has particularly emphasized the human factor, because this human factor is exactly what links the idea, technology, progress and development of the uncertainty that characterizes the startup.

In conclusion, the startup is a concept whose main activity is in connecting in- 
novative ideas with reality and transforming them into products or services, but in a specific modus by studying the reaction of target consumers and requiring their feedback, with the aim of identifying optimal operations.

It is obvious that the concept of the entrepreneurship has changed over time, but it certainly kept its basic characteristic - the desire and need for risk-taking and the creation of something new. In today's context, entrepreneurship is increasingly linked with the power of new technologies and knowledge about them. Precisely on this basis of joint technological achievements and formal education, knowledge and science technology parks were created.

The terms technopol, technology parks, science parks, research parks are being widely used as synonyms. Technopolis are according to M. Castells and P. Hall defined in few basic forms, that being: facilities with high tech design; science parks (and towns); technology parks; complete technopolis who are instruments of regional development and decentralization; metropolis of the industrial world (Castells, Hall, 1994, 56). In this sense, we can actually talk about synonyms, since each of the proposed expression is characteristic of a certain part of the world. Thus, the term Research Park is characteristic in the United States, Science Park in Europe, a technology park in Asia. According to other authors, we can talk about the "British model" which is characterized by the name science park, and "Mediterranean model" characterized by the name technology park (Vilà, Pagès, 2008, 142-149). Quoted authors state that in the European area both terms scientific and technological parks coexist, and there are no major differences in their concepts. One point of divergence would be their size - scientific parks are generally smaller and the main purpose is scientific research, while technology parks are larger and support production. Common to all these different names is a public - private partnership that supports the flow of knowledge, usually between tenants and higher education institutions, and contributes to regional economic growth.

The important role of technology parks is evident in the fact that since 1984, operates International Association of Science Parks and Areas of Innovation - IASP, worldwide network of science parks and innovation areas, which has the status of a special consultant with the Economic and Social Council of the United Nations. This organization defines science parks as an organization guided by specialized professionals, whose main aim is to increase welfare of the community by promoting the culture of innovation and competitiveness and all of that through activities of its related business and educational entities.

Technology parks represent a planned, designed and organized units that have a fully equipped space in terms of infrastructure and other forms of assistance and support. Its customers, often labeled as "tenant" are offered various forms of assistance and benefits (office space, equipment, intellectual services, all with minimal financial participation), with the aim of developing the ideas from the phase of formation and incubation, to the stage of the finished product ready for the market. 
They are being established and developed in collaboration with higher education institutions, and thus represent a link between knowledge, education, high technology and entrepreneurship.

According to I. Žuvela we can identify the generally accepted goals of technology parks, as follows:

(a) the creation of new forms of cooperation between scientific research and modern production, thus more quickly transmitted scientific results in an economic area

(b) a method of modernization leads to the acceleration of restructuring of the existing industry

(c) they accelerate the development of the entire region through job creation, infrastructure, by raising the scientific and cultural standards

(d) they are raising the level of corporate culture and ethics (Žuvela, 1993, 67).

Technology parks have no strictly defined organizational form, but we can talk about the theory of technology parks.

According to the European Commission report prepared by the Directorate General for Regional and Urban Policy there are two concepts of technology parks (http:// ec.europa.eu/regional_policy/sources/docgener/studies/pdf/stp_report_en).

The first is the "triple helix" concept which is generally associated with the concept of science parks, and involves a creative interaction between government, universities and research centers and businesses (business), and the addition of market / society creates the concept of "quadruple helix".

Another concept puts the eight criteria for creating successful scientific - technology park, and the most important criteria being the need of support by the national and regional economic - development policies, necessary connections and networking of all residents. Such parks should be considered passageway, which lead to a business opportunity, but not a destination.

Historically technology parks are created following the idea of clusters. Already in the late forties and fifties of the 2oth century some of the first forms of technology parks were created: Menlo Park, the Stanford Industrial Park (now the Research Park) which was the forerunner of what is now known as Silicon Valley. Silicon Valley today represents the area of greatest concentration of high-tech innovators of the IT sphere.

The first technology park is considered to be the University City Science Center, founded in 1963 by the University of Philadelphia.

Although at first beginning of technology parks was linked to the area of the United States, in Europe universities of Canfield and Cambridge recognized the American idea, but it took a while until in the 1980 os intervention of the British government encouraged coordination of universities and industry. 
In the period from 1970 to 1984, the first truly European technology park was created: Sophia Antipolis in France, which is primarily focused on the area of computing, electronics, pharmacology and biotechnology. During this period a series of technology parks was founded, the so-called Centers Regionaux innovation et de Transfer de Technology.

In the early eighties of the 2oth century the first technology parks in Italy (Trieste) and Germany (Heidelberg) were founded.

In Spain, in 1985 the Bilbao Technology Park was founded, but only in 1996 when the Barcelona Science Park was founded, academic community became involved in the operation of technology parks.

Of course, development was visible in the Asian region. In the 1990 financial institutions recognized the importance of investment and support of the technology centers, parks, incubators of knowledge.

According to John Allen (2007, Third Generation Science Parks, Manchester Science Parks, Manchester, UK) there is a concept of three generations of scientific and technology parks (http://ec.europa.eu/regional_policy/sources/docgener/studies/pdf/stp_report_en.pdf):

(a) The first generation - parks established before and during the 1980 os of the 2oth century, characterized by the landscaped environment with quality buildings, connection to higher education institutions, and active links with higher education institutions in the field of technology transfer and innovation but only within companies - residents

(b) The second generation - parks established in the 1990s of the 2oth century, who began to spread range of services offered by the residents especially those involved in the startup and early stage technology businesses, and strengthening pro-active connections (networks) that support innovation

(c) Third Generation - 2006 at a workshop in Manchester thirty leaders of technology parks, academic researchers, consultants and persons working on development met and concluded that the third generation is characterized by all the characteristics of a good fleet of second-generation, and in addition to the creation and organization of quality physical environment that will encourage a high level of creativity and innovation.

The first technology park in Croatia was founded in 1993, as a society called KONČAR - Technology Park Ltd., which began with the work in 1994. Today it is a society known as the Technology Park Zagreb. The first director Marijan Ožanić in his book "The work of the Technology Park Zagreb - 10 years of development" describes the confusion and misunderstanding of the public (and even business) about the very concept and purpose of such companies (Ožanić, $2004,12)$. 
The actual investment in technology infrastructure in Croatia started in 1998. In Croatia there are seventeen technology parks and business incubators, of which the most important technology park, Technology Innovation Center Rijeka was created in 1997. As numerous studies show, technology parks have undoubtedly contributed in economic growth and development and entrepreneurship in general.

\section{CASE STUDY- TECHNOLOGY PARK VARAŽDIN}

Research was carried out in which the participating were legal entities - tenants of the Technology park Varaždin who are participants in the incubation process. It is possible to enter the technology park in the incubation process, and in the form of commercial tenants. Commercial tenants are those who do not meet the conditions for the incubation process, and therefore are not of interest for this study.

The research topic was to create a profile of tenants of Technology park Varaždin and analyze their "housing" in the present park, with the aim of determining the role of the Technology park Varaždin in the development of their entrepreneurial venture.

\section{RESEARCH METHODOLOGY}

The study was conducted by analyzing secondary data from the available literature and publicly published reports of the Technology park Varaždin, as well as information on the legal form of the tenants that are obtained by examining the appropriate public registers. The analysis of these secondary data prepared the foundation for the formation of ways of collecting primary data and proposal of hypothesis (Ivetić, 2016, 32-66).

Furthermore, research was conducted by analyzing the primary data collected by the questionnaire that has been created on the Google Spreadsheets service. It should be noted that the legal entity tenants of Technology park Varaždin were referred to using the term "tenant".

The survey questionnaire consisted of a total of twenty questions. Questions were grouped as follows:

- The first group of questions was used for profiling tenants (the duration of business, number of employees, the primary activity, duration of residence in the Technology park) with which data secondary data essential for tenants was associated

- the second set of questions were used to identify the reason for entry into the Technology park, grade the severity of administrative requirements; identify the expectations and level of fulfillment of expectations, and define the maximum benefits and the greatest lack of housing

- the third group of questions was used to evaluate degree of logistical support 
of the Technology park Varaždin and identify the required services that are not currently offered

- the fourth group of questions was used for evaluating claims related to the affect of housing in the Technology park on entrepreneurial venture of its tenants.

The survey was conducted during the period from $7^{\text {th }}$ to 13th March 2016 in such a way that the tenants of the Technology park Varaždin were invited to fill out the questionnaire via the enclosed online forms (Ivetić E., 2016, 32-66). Call for filling the questionnaire was sent to thirty-one occupant, and feedback was given by fourteen occupants. Regarding the specific target group of the study, it is considered that the resulting sample represents $45 \%$ of the target population and thus is representative and valid.

The following hypotheses were proposed:

(1) Technology park has met the expectations of tenants

(2) Entering the incubation process is not overly burdened with the administrative requirements

(3) Housing in the Technology park has positively affected entrepreneurial venture.

\section{RESULTS OF THE SECONDARY DATAANALYSIS}

Such secondary data are the basis of this study, therefore, are exposed in the following order.

Technology park Ltd. is in form of a limited liability company, with the primary activities being: incubation center for innovative startup companies, establishment of a mechanism for improvement of existing technologically innovative companies, improving knowledge transfer with universities and development centers into the economy, networking companies, educational institutions, development agencies and innovative individuals, and changing the perception towards innovation as a foundation of a new economy. As to ownership structure, to crowners are City of Varaždin, Faculty of Organization and Information Science and the University North. From the register of visible is a list of activities, of which stand out the following: business control, providing advice and assistance to businesses and public services in planning, organization, efficiency and control, management information, advising management; encourage research and development in the field of technological and natural science; promotion of business cooperation, technology transfer and commercialization of research results. From the foregoing, it is evident that according to all supra mentioned iregarding characteristics and activities of technology parks, Technology park Varaždin really belongs to the category of technology parks. This project was started in 2003 . 
The conditions for entry into the incubation process are as follows:

- project in the field technology that has the intention of establishing some form of legal personality, with the advantage of having activities in the field of new technologies (ICT, biotechnology, nanotechnology),

- project under consideration may be in one of the following forms: - an innovator or an individual with an entrepreneurial startup idea- company - existing company (up to 4 employees) which is in phase of growth or change of activity in relation to the technology of interest- company that is launching a new project, and run the incubation of only one segment - a new spin-off company or subsidiary of a firm located outside Varaždin whose activity corresponds to that mentioned above; a new product or a new service that is going to be developed or improved should be able to commercialize within at least two years

- candidates usually need to have a concept of the business plan, and elaborate financial scheme

- the candidate must demonstrate the ability to lead and project management, skills; the candidate must employ new workers, and demonstrate the ability to pay monthly expenses

- applicants must be prepared for coexistence in incubation space and must be able to promote projects of other tenants and institutions of Technology park Varaždin.

In addition to the incubation process, Technology park Varaždin offers as well preincubation process in terms of identifying the commercial components of technologically innovative projects, and implementation of the preincubation activities for the purpose of entering the incubation.

Incubation process includes the following segments:

(1) Accommodation: privileged price in a way that: - the first year of residence in the TP Varaždin tenants pay $25 \%$ of the market price, the second year $50 \%$ of the market price, third year $75 \%$ of the market price, and the fourth year of full market price; the first year of residence in the CEC (a part of Technology park Varaždin) is fully free, the second year is paid $25 \%$ of the market price, third year $50 \%$ of the market price in the fourth year $75 \%$ of the market price, and the fifth year of full market price.

(2) Assignment of the necessary infrastructure: Internet access, meeting rooms, conference hall, presentation equipment, video camera and digital camera (free for all tenants), fax machine is free for all tenants, 3D equipment

(3) The improvement and development of the tenants company: while entering the incubation process each tenant gets a mentor, who works daily with the tenant. 
(4) Upgrading and development projects: development of the project, market analysis; assisting in financial analysis and networking with other tenants, companies and educational institutions.

The next phase is post incubation process - period after the company ended its incubation process. Further cooperation includes preparations for the successful completion of incubation, finding new locations and adequate maintenance. As well there are offered services like motivation and awareness, marketing and PR, creative workshops, networking, conferences, counseling.

According to the results of secondary data analysis it is concluded that Technology park Varaždin is active in the field of promoting the development and transfer of knowledge, which is done through participation in various projects, by providing an adequate infrastructure to its tenants and the development of new concepts and business ideas.

\section{RESULTS OF THE PRIMARY DATA ANALYSIS}

Below are presented the results obtained by a questionnaire survey. The introduction refers to the legal form of the respondent's limited liability company, which is determined from the secondary data (by checking the appropriate registers). Results are displayed graphically and in tabular form, so that they can be quantified. Technology park Varaždin is referred to as TPVaraždin (Ivetić, 2016, 32-66).

Figure 1.: Duration of operations

1. How long has your company been operating?

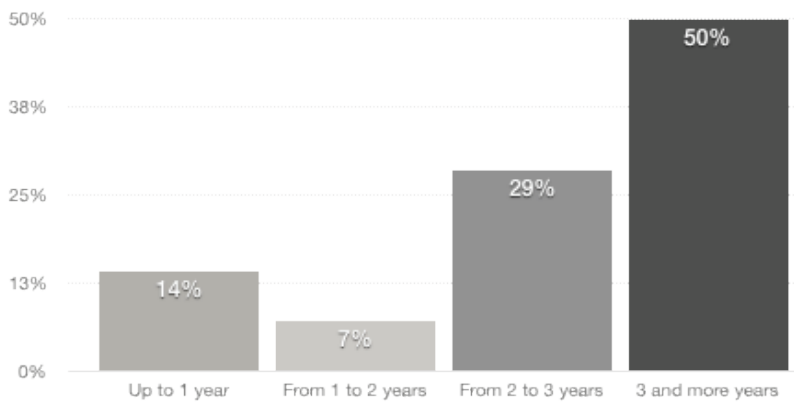

Source: Authors.

The results show that the largest proportion of respondents - $50 \%$ are operating three or more years, $28.6 \%$ are operating from two to three years, $14.3 \%$ are operating to one year, and $7.1 \%$ are operating from one to two years. 
Figure 2.: Number of employees

2. How many employees does your company have?

$50 \%$

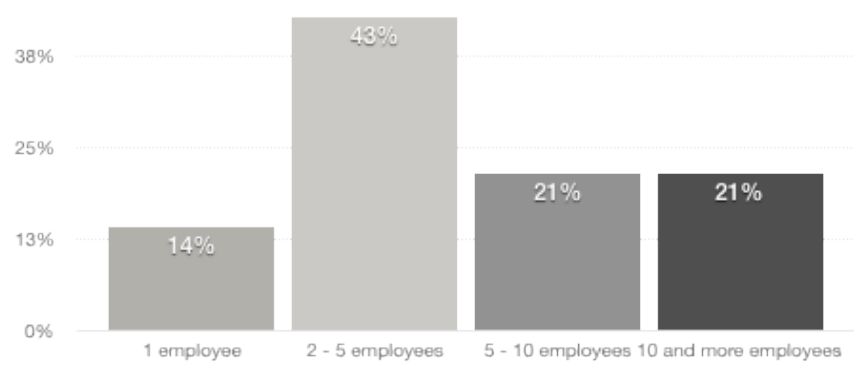

Source: Authors.

The results show that the largest proportion of respondents, $42.9 \%$ have from two to five employees and an equal share of the $21.4 \%$ of respondents have employed five to ten, or ten or more employees. Only 14.3\% of respondents have one employee.

Figure 3.: Primary business area

3. What area is your primary business in?

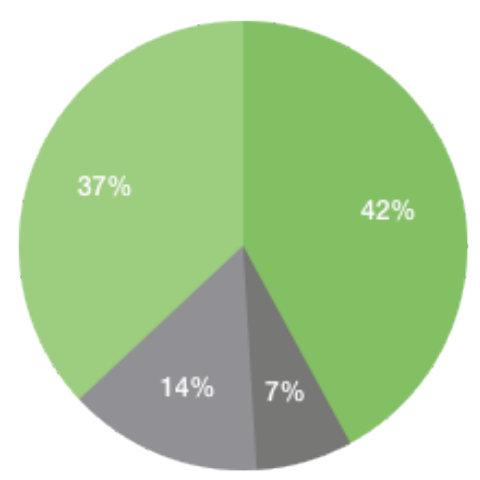

Programming

Development of new technologies

Design

Other

Sale

Source: Authors.

The result show that the largest proportion of respondents, $42.9 \%$ are primarily engaged in programming, while $37.7 \%$ said the category "Other"; $14.3 \%$ of respondents are engaged in primarily the development of new technology, and $7.1 \%$ in design. 
Figure 4.: Duration of the tenancy

4. How long have you been a tenant of TP Varaždin?
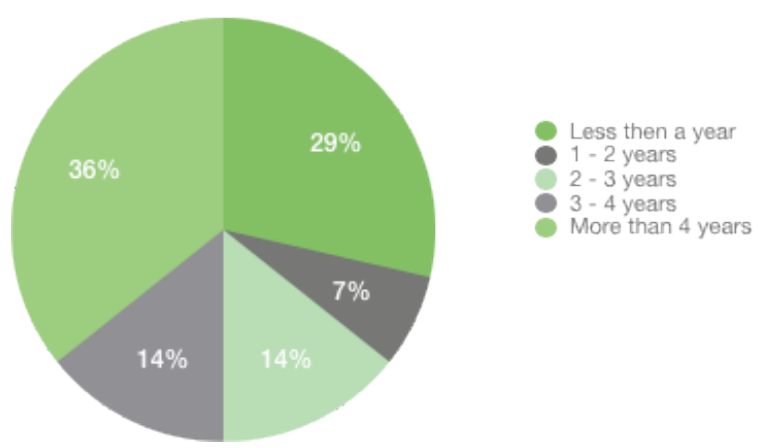

Source: Authors.

The results show that the largest proportion of respondents, $35 \cdot 7 \%$ have been a tenant in TPVaraždin more than four years, 28.6\% less than a year, the same proportion of $14.3 \%$ have been a tenant from three to four years, and the lowest percentage of respondents, $7.1 \%$ are in TPVaraždin from one to two years.

Figure 5.: Duration of the previous tenancy

5. If you are no longer a tenant, how long you have been a tenant of TP Varaždin?

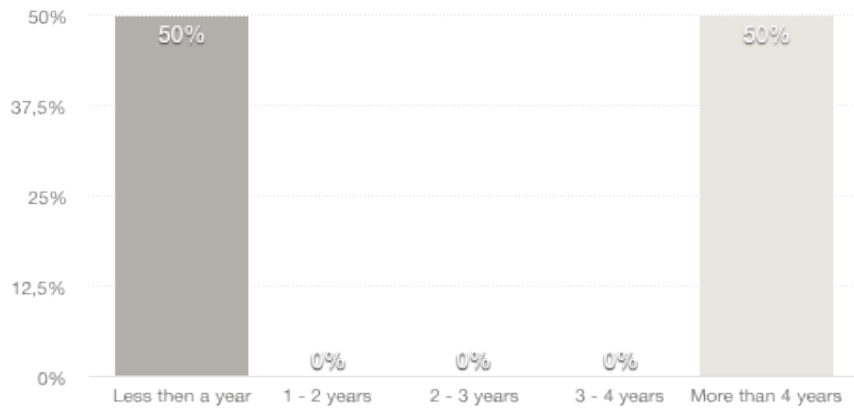

Source: Authors.

Out of the fourteen tenants, two in the meantime completed the process of housing in TP Varaždin, where one respondent was a tenant under a year, one more than four years. 
Figure 6.: Source of information

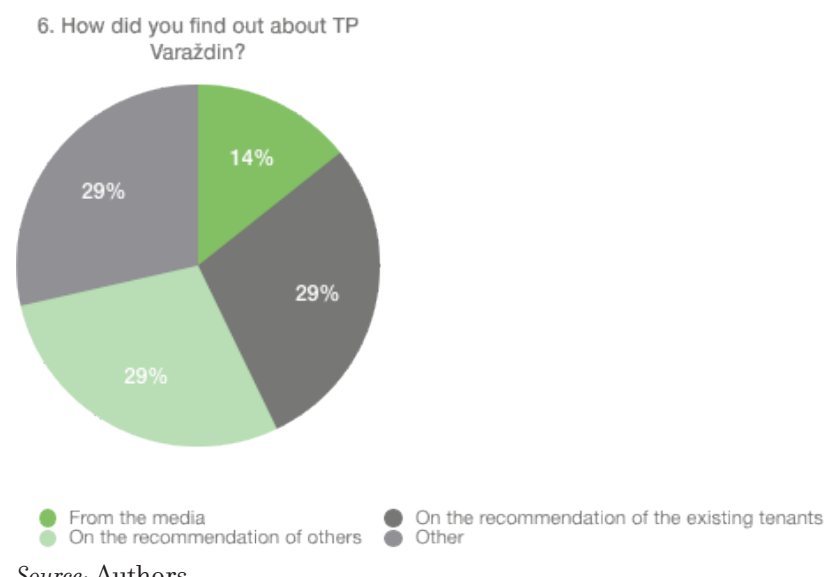

Source: Authors.

The results show that the respondents primarily learned about TP Varaždin through referrals of existing tenants, by the recommendation of other tenants or otherwise. The smallest share of respondents found out about the TP Varaždin from the media.

Figure 7.: Reason for entering into TP Varaždin

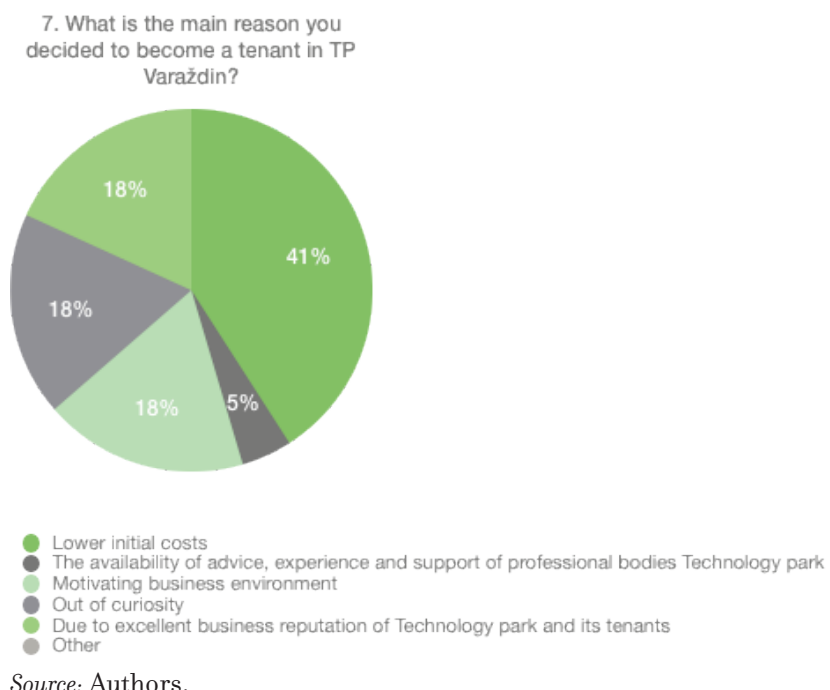

Source: Authors.

The results show the primary reason for entering the TP Varaždin - lower initial costs, but the least relevant reason is availability of support. 
Figure 8.: Severity of administrative requirements

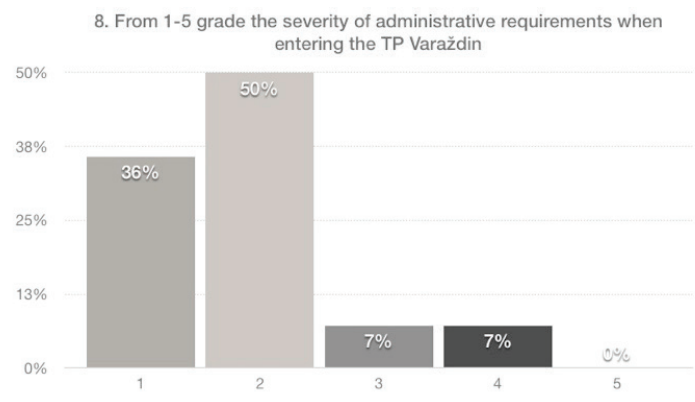

Source: Authors.

The results show that half of respondents are ranking the weight of administrative requirements with grade 2 , and the average score is 1.42. Taking into account that the score 1 represented very simple requests, and 5 extremely difficult, it is evident that the average score expresses simple requests.

Figure 9.: Expectations

9. What did you expect from the habitation in TP Varaždin when you were entering the incubation process?

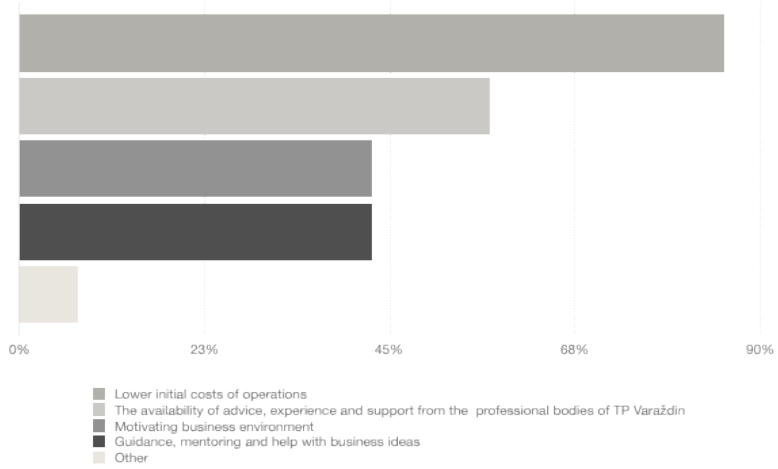

Source: Authors.

The results show that the respondents primarily expected lower initial costs, and then the availability of advice and support of professional bodies. $42.9 \%$ of respondents expected motivating business environment. 
Figure 10.: Expectation fulfillment

10. From 1-5 assess the degree of fulfillment of your expectations in the current state of housing in TP Varaždin

$60 \%$

$57,1 \%$

$45 \%$

$30 \%$

$15 \%$
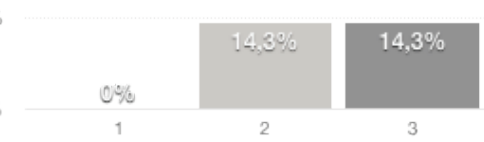

3
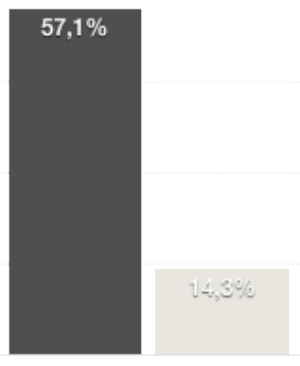

Source: Authors.

The results show that the largest proportion of respondents rated the degree of fulfillment of the expectations with grade 4 , and the average score is 3.71. Taking into account that the score 1 represented a failure to fulfill expectations, and 5 absolute fulfillment of the same, the average score expresses the fulfillment of expectations.

11. Write concisely what you think is the greatest benefit of your housing in TP Varaždin

Table 1.: Greatest benefits

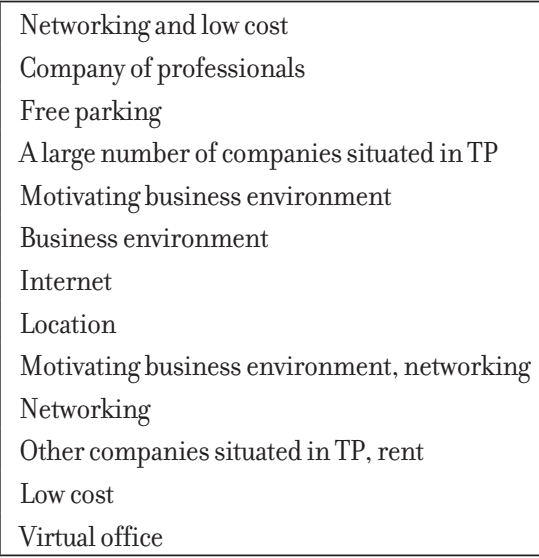

Source: Authors.

The results show that as the greatest benefits are identified networking (establishing personal and business links), business environment, and the cost and location. 
12. Write concisely what you think is the greatest defect of your residence in TP Varaždin so far?

Table 2.: Greatest defects

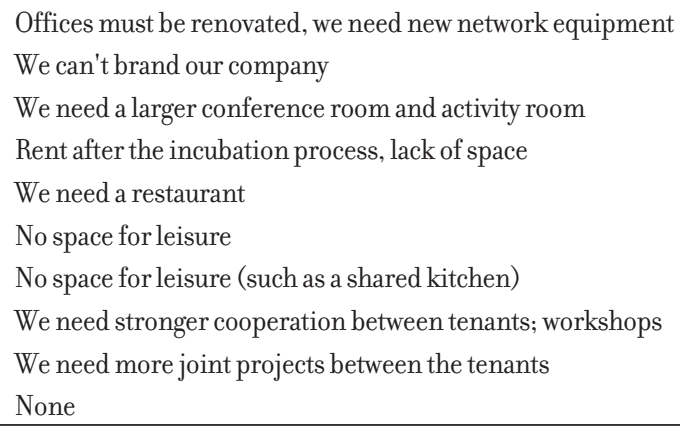

The results show that the greatest defects of previous residence are lack of adequate office space and lack of space for leisure.

Figure 11.: Logistic support

13. Are you satisfied with logistic support by TP Varaždin?

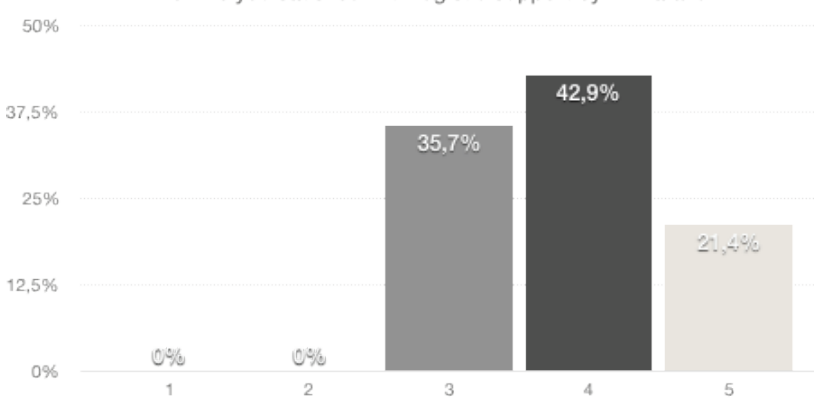

Source: Authors.

The results show that the largest proportion of respondents rated satisfaction with logistic support with grade 4 , and the average score is 3.85 . Taking into account that the score 1 represents dissatisfaction and 5 absolute satisfaction, the average score expresses satisfaction with logistic support. 
14. Write concisely what would you add to the list of services offered by TP Varaždin

Table 3:. List of required services

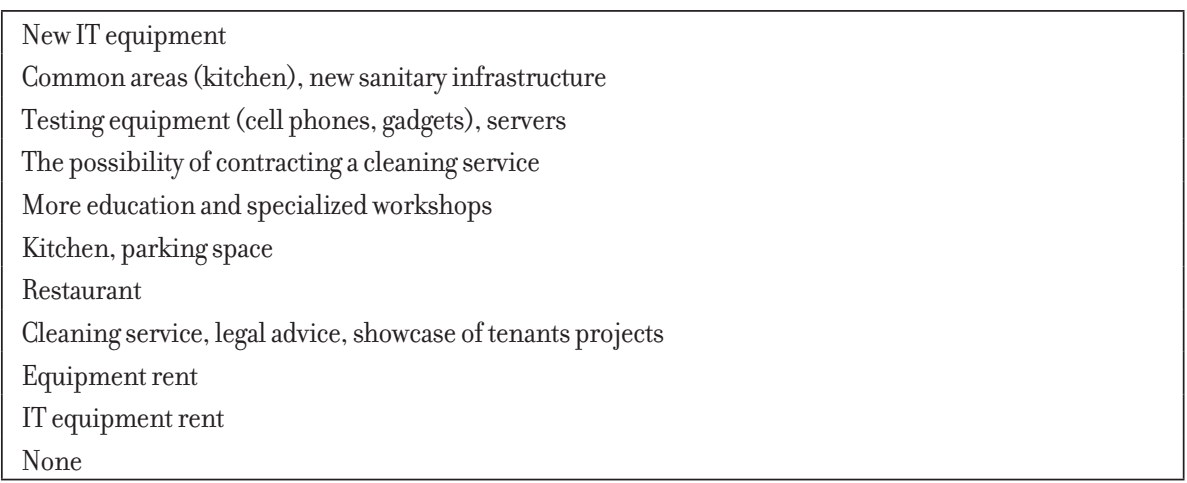

Source: Authors.

The results show the greatest interest in the availability of specialized equipment, organizing kitchen, restaurant and cleaning services.

Rate the following statements $(15 .-20$.) on a scale from 1 (completely false) to 5 (completely true):

Figure 12.: Impact on business thinking

15. Housing in TP Varaždin has affected our business thinking.

$70 \%$
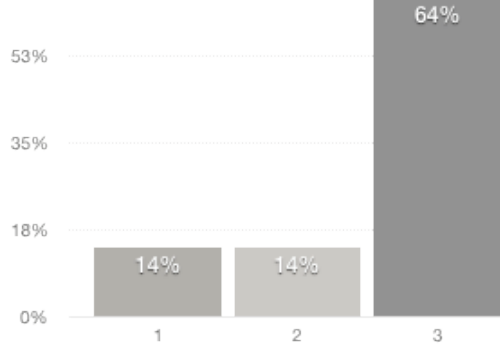

Source: Authors.

The results show that the largest share of respondents assessed the impact of housing in TP Varaždin on business thinking with grade 3, and the average score is 2.71. Average score therefore expresses the average power of influence. 
Figure 13.: Impact on the introduction of new technologies

16. Housing in TP Varaždin has introduced us to new technologies.
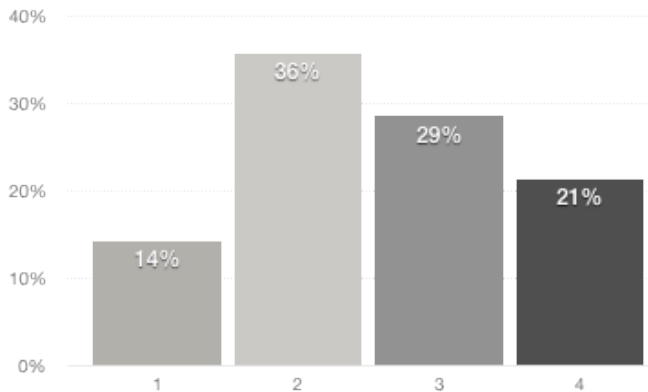

Source: Authors.

The results shows that the largest proportion of respondents rated the degree of influence of housing in TP Varaždin on the introduction of new technologies with grade 2, and the average score is 2.57 . Average score therefore expresses the average power of influence.

Figure 14: Impact on the internationalization of business

17. Housing in TP Varaždin helped the internationalization of our business.

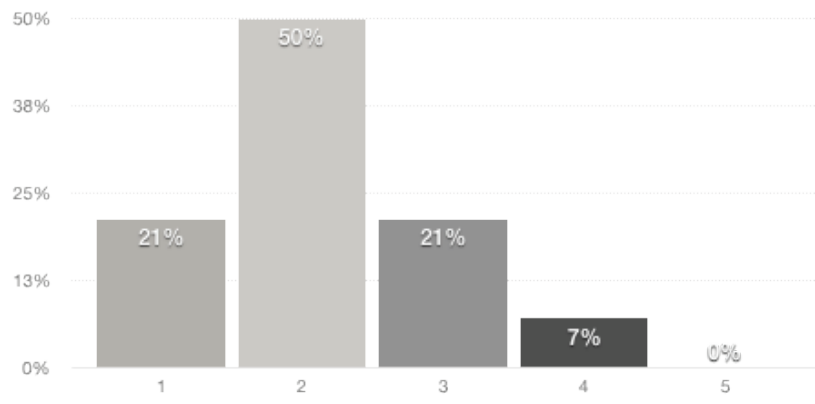

Source: Authors.

The results show that the largest proportion of respondents rated the degree of influence of housing in TP Varaždin on the internationalization of business with grade 2, and the average score is 2.14. Average score therefore expresses a very bad influence. 
Figure 15.: Impact on the creation of new business contacts

18. Housing in TP Varaždin helped us in making new business contacts.
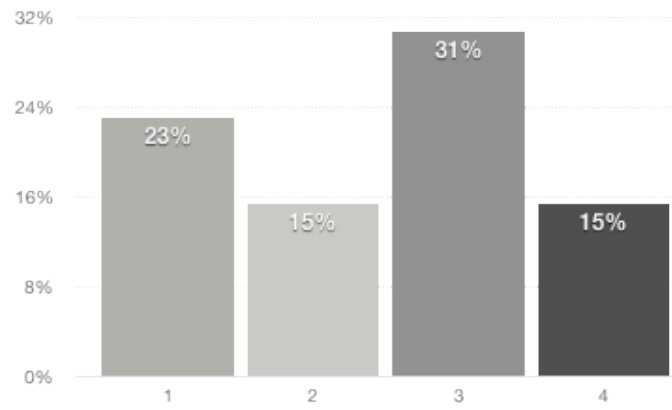

Source: Authors.

The results show that the largest proportion of respondents rated the degree of influence of housing in TPVaraždin on achieving business contacts with grade 3 , and the average score is 2.64. Average score therefore expresses the average power of influence.

Figure 16.: Impact on further education

19. Housing in TP Varaždin was an encouraging environment for further education and training.

$50 \%$

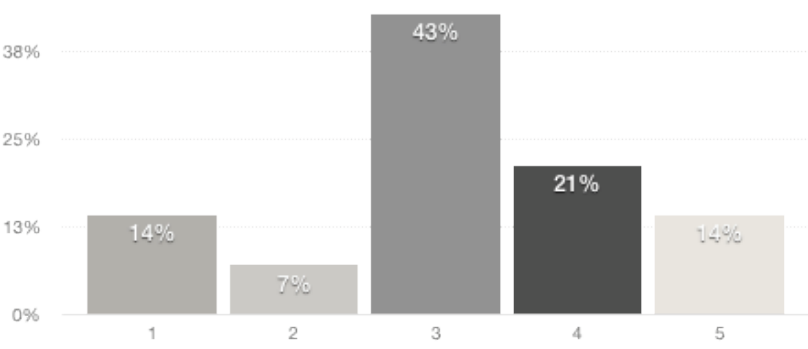

Source: Authors.

The results show that the largest proportion of respondents rated the degree of influence of housing in TP Varaždin on further education with grade 3 , and the average score is 3.14. The average score therefore expresses the average power of influence. 
Figure 17.: Impact on cost reduction

20. Housing in TP Varaždin enabled the reduction of operating costs.

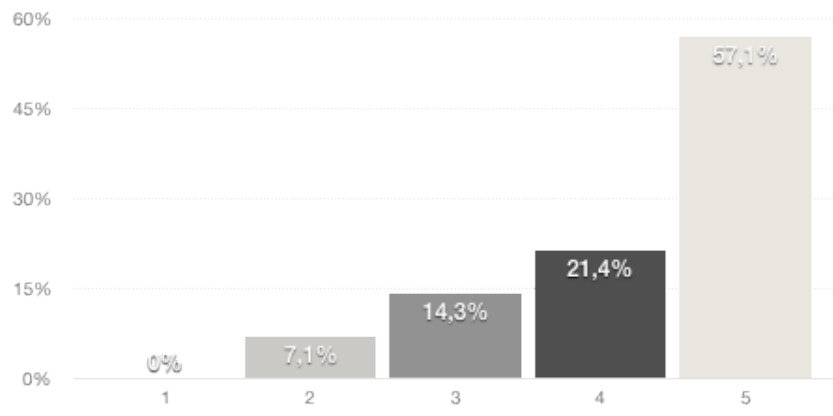

Source: Authors.

The results show that the largest proportion of respondents rated the degree of influence of housing in TP Varaždin in reducing operating costs with grade 5 , and the average score is 4.28 . The average score therefore expresses a high power of influence.

\section{ANALYSIS OF RESULTS AND PROCESSING OF THE HYPOTHESIS}

Given the research conducted, and the combined primary and secondary data, the following is concluded. On the basis of the first group of questions from the questionnaire it is determined that $50 \%$ of respondents operate three or more years, with the largest proportion of respondents' employ from two to five employees. The primary activity of the respondents programming, followed by other activities, and in third place in the representation of developing new technologies. From the results it is evident that the profile of tenants is corresponding to profiles which are discussed in theory and comparative practices - this is mostly about small businesses or micro enterprises.

On the basis of the second group of questions reasons for joining the Technology park were identified. The primary reason is lower initial costs, while the least relevant reason is professional bodies support. Results are associated with the current economic and social situation, which is extremely unfavorable for starting a new job, and this in the context of high costs and administrative barriers. From the research results it can be concluded that the respondents decided to enter the technology park just because of the possibility of bridging these two reasons - lower initial cost and very simple administrative requirements when entering the system incubation. Furthermore, the identified expectations and the degree of fulfillment of expectations when entering the incubation process, where it can be seen that the tenants primarily expected lower start-up costs, and then the availability of advice and sup- 
port of professional bodies, in that respondents were satisfied with the fulfillment of expectations in the current phase of its housing. Defined are the biggest benefits of the former residence- primarily networking, business environment, low cost and convenient location. At the same time as the greatest shortcomings of previous residence the majority of tenants identified lack of adequate space.

On the basis of the third group of questions it was expressed the degree of satisfaction with the logistic support and it was identified the need for services that are currently not yet available. The list of proposals of such services include the need for new equipment, organized food and service cleaning offices. Results are associated with the current project extension TP Varaždin, and the announced investment in infrastructure.

On the basis of the fourth group of questions it was identified the influence of housing in Technology park Varaždin on business and related activities. It was expressed average impact on business thinking, introduction of new technologies, establishing business contacts and further education. Agreat impact was expressed on the reduction of operating costs, and extremely bad impact on the internationalization of business.

Hypothesis 1: The Technology park has met the expectations of tenants

The hypothesis is accepted. Analyzing the results of the questionnaire shows that the tenants when entering primarily expect lower operating costs and availability of advice and support from professional bodies. The greatest benefits of previous residence are considered networking, business environment and lower operating costs. Responding to a direct question about the degree of fulfillment of the expectations it was expressed a high degree of fulfillment of expectations.

Hypothesis 2: Entering the incubation process is not overly burdened with the administrative requirements

The hypothesis is accepted. Analyzing the results of the questionnaire revealed current simple administrative requirements when entering the incubation process, and expressed satisfaction with the provided logistic support.

Hypothesis 3: Housing in the Technology park has positively affected entrepreneurial venture

The hypothesis is accepted. The analysis of rating statements related to the impact of housing determined the average power of influence on the positive aspects of business development, in terms of impact on business thinking, introduction of new technologies, establishing business contacts and further education. As expected, the greatest impact was shown on reducing operating costs, which is again associated with the current economic situation. However, it was shown surprisingly low power impact on the internationalization of the business, but also bringing this into the context of the current economic situation we can conclude that the primary goal of these entrepreneurs was to keep their business alive, while the internationalization was only potential additional benefit. 


\section{CONCLUSION}

The results of the study show that Technology park Varaždin has a role in the entrepreneurial process of its tenants, and meets their expectations. However, it is necessary to work on the development of infrastructure, and enabling the creation of a complete range of business and supporting informal content. In addition, it is necessary to work on media exposure, which is quite unexpected given the very function of the Technology park and its links with modern technologies. Without additional efforts the role of Technology park Varaždin could be reduced to the purpose which, unfortunately, has a large number of Croatian technology parks and centers - an area that generates lower operating costs.

The hypothesis were made according to the resulted of the survey which was made on the small sample; only 14, occupants. The Technology Park Varaždin had only 14 , tenants and that is the reason for such a small sample.

It is recommended to extend the research of other technological parks in Croatia and in Europe. 


\section{REFERENCES}

Bobera, D., Hunjet, A., Kozina, G. (2015) Poduzetništvo. Sveučilište Sjever, Koprivnica/Varaždin

Brusić A., Gvitanović V., GregovZ., KutnjakV., Tomić D., Žanić V., (2009). Poduzetništvo 1, Grupa VERN d.o.o., Zagreb

Castells M., Hall P., (1994). Technopoles of the worlds: The making of twenty-first-century industrial complexes, Routledge

Hisrich R. D., Peters M. P., Shepherd D. A., (2011). Poduzetništvo, MATE d.o.o., Zagreb

Hunjet, A.; Kozina, G., 2014. Osnove poduzetništva, Sveučilište Sjever, Koprivnica/Varaždin

Hunjet, A., Kozina, G., Kurečić, P. The Role of Higher Education Institutions in the Development of Entrepreneurship Competences on the Study Programs Other than Economy, 9th Economic and Social Development Conference Proceedings, Koprivnica, (2015): 620-629

Hunjet, A., Kozina, G., Milković, M., Stjecanje znanja i vještina za budućnost u poduzetništvu, „Učenje za poduzetništvo", (2012): 103-115

https://www.sba.gov/content/startups-high-growth-businesses

http://steveblank.com/2010/01/25/whats-a-startup-first-principles/

http://ec.europa.eu/regional_policy/sources/docgener/studies/pdf/stp_report_en.pdFSetting up, managing and evaluating EU science and technology parks, 2013

Ivetić E., (2016). Diplomski rad br. 98/PE/2016, Uloga tehnoloških parkova u poduzetničkom procesu: primjer Tehnološkog parka Varaždin, Sveučilište Sjever

Ožanić M., (2004). Tehnološki park Zagreb - 10 godina razvoja, Tehnološki park Zagreb d.o.o.

Ries E., (2013). Lean startup, MATE d.o.o., Zagreb

Vilà P. C. , Pagès J. L., Science and technology parks. Creating new environments favourable to innovation, Paradigmes, Issue no. o, May, (2008): 142-149

Žuvela I., (1993). Znanstveno-tehnološki parkovi; Zbornik radova Ekonomskog fakulteta u Rijeci 

